\title{
COVID-19 and social differentiation in African agriculture
}

\section{Summary}

Commercialisation has tended to advantage larger farms and businesses, despite the discourse of smallholder empowerment in the African Union's Comprehensive Africa Agriculture Development Programme (CAADP). Intersectional disadvantage relating to gender, ethnicity, citizenship and generation underpins distinctions between smaller-scale and larger-scale producers.

Those who have been advantaged by commercialisation have greater access to capital and labour and therefore have greater resilience capacity to deal with shocks such as COVID-19. Equally, without targeted policy measures to support them, individuals who are less advantaged overall have less resilience capacity to deal with the effects of COVID-19. This reinforces their general disadvantage in a recursive way.

Some individuals who demonstrate ingenuity, resilience and agility have been able to circumvent these challenges, for example by switching within or stepping out of the value chain. However, this is uncommon and still requires them to overcome greater challenges than others who have larger, more robust businesses.

In the first year of the pandemic, COVID-19 itself had the type of short-term effects that result from other short-term shocks. Early data did not show that COVID-19 had caused changes that could have a longer-term impact on agrarian relations, such as distress land sales or permanent migration. However, these types of eventualities could become possible as COVID-19 becomes endemic. This would have long-term implications for agrarian relations, mediated through changes to land tenure or ownership of capital assets.

\section{Helen Dancer and Imogen Bellwood-Howard'}

\section{Introduction}

This brief presents a summary of key findings from a multi-country study of social differentiation in African agricultural value chains in the context of COVID-19 (Bellwood-Howard and Dancer, 2021). It aims to understand how trends in the politics and participation of different actors in agriculture have contributed to patterns of social differentiation, and how these patterns have interacted with the shock of COVID-19. It brings attention both to the implications of political decision-making and the effects of the pandemic on value chain structures and those working within the sector.

The findings are based on multi-country empirical research conducted between 2016 and 2020 by the Agricultural Policy Research in Africa (APRA) programme, which studied the consequences of different pathways to agricultural commercialisation across value chains in Ethiopia, Ghana, Malawi, Nigeria, Tanzania and Zimbabwe.

The African Union's CAADP is the dominant continent-level policy framework for agriculture and influences national policy. It operates with the logic that the successes of large-scale interests and investment in agricultural value chains will trickle down to smallholders. Contract farming and outgrower programmes are examples of how this may happen, although their efficacy is not universally proven.

While large-scale actors have increasingly made entry into African agriculture, medium-scale farmers are also on the rise in many places, often using their income from other sources to enter agriculture. However, smallholder agriculture continues to provide most of the production in African value chains. While agricultural commercialisation has been suggested as one of the drivers of contemporary growth in Africa it is also one of the processes that has contributed to social differentiation.

Helen Dancer is a Senior Lecturer in the School of Law, Politics and Sociology, at the University of Sussex, and Imogen Bellwood-Howard is a Research Fellow at the Institute of Development Studies. 


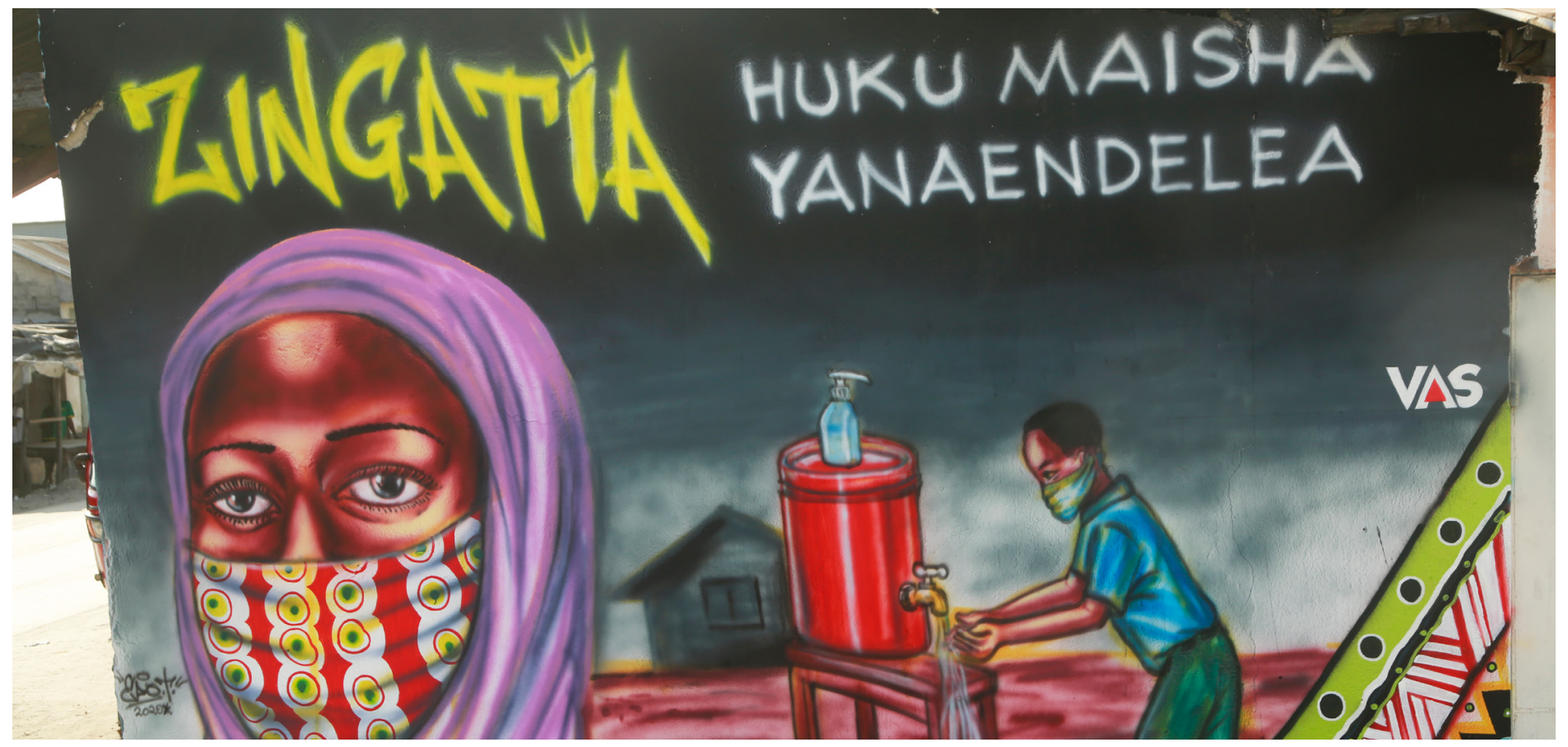

Street artists have drawn attention to the resilience of women in dealing with COVID-19 (MasterCard Foundation, no date)

(c) Rasheed Hamis and Nuktar Muktadha

\section{Politics and power in African agriculture}

In recent years, political settlements approaches to policy analysis have become favoured in the development sector. These approaches analyse the dynamics, organisation and exercise of power and distribution of benefits between elites, and their relationship with formal and informal institutions that underpin political systems.

Political settlements analysis, however, frequently pays insufficient attention to the role of non-elite actors, wider social movements and private spheres, and typically does not consider gender dimensions (O'Rourke, 2017). Demography and technological advances, as well as exogenous drivers of change (including shocks such as COVID-19), also shape political settlements (Kelsall and vom $\mathrm{Hau}, 2020)$. Key findings from APRA research bring attention to these frequently neglected issues in political settlements analysis of agricultural value chains. Paying attention to these critiques of mainstream approaches, we asked:

1. What can political settlements analysis tell us about agricultural value chains and responses to COVID-19 in the countries studied?

2. How are structures and power relations throughout the value chains and actors' responses to COVID-19 related to social differentiation in the context of African agriculture?

Answering these questions involves understanding how longterm, politically influenced patterns of change have shaped social differentiation in ways that in turn affect the ability and resilience of different actors to respond to shocks. Furthermore, it involves understanding the recursive effect of those shocks on social differentiation.

This brief is based on the work of APRA teams in six countries across 11 value chains (Table 1). All countries except Tanzania had some form of lockdown and the nature of the restrictions and impacts of the pandemic in terms of access to markets, labour and other inputs was similar, but to varying extents across countries.

\section{Long-term trends in social differentiation}

Political systems, national and local land tenure systems, and local-scale relations within households and communities shape people's trajectories in commercial agriculture. The nature of people's interest in agricultural land remains the most significant determinant of agrarian relations and the most important and striking factor for social differentiation. Many women and migrants face challenges in securing their interests in land and decisionmaking power over it. Access to land is closely tied to access to labour and other capital, credit and inputs. Many larger farms and businesses are corporate in nature. Such businesses are more likely to be owned by men, autochthons, household and lineage heads, older people and particular ethnicities, than by women, migrants, junior household and lineage members, and youth.

Labour relations often interact with land access. Unless they own or manage land themselves, women and youth tend to be obliged to provide labour to family members, often for free. However, women and young men can sometimes mobilise kinship relations to gain access to land that they have worked on in the past. Women tend to engage in lower value, local markets, rather than export markets, and have weaker access to capital and to productive machinery, for example oil presses.

There are examples from all countries where advantage is conferred to certain political actors or groups, such as smallholder lobbies or larger-scale businesses through elite relations. These include:

- Preferential land access for bigger companies facilitating largescale land acquisitions in the context of liberalisation across many countries; or conversely, centralised land reform based on politics and citizenship, as in Zimbabwe's Fast-Track Land Reform Programme.

- Nepotistic manipulation of agricultural input schemes, and the arrangement of land and financial systems to advantage these parties. 
- Market interventions by governments in the form of subsidies, tax breaks, import and export controls, marketing boards and state research agendas to advantage investors or target voter groups.

\section{Short-term effects of COVID-19}

In the first year of the pandemic, COVID-19 itself had the type of short-term effects that result from short-term market changes such as price changes, export bans, or input provision shocks. The most immediate and noticeable effects of COVID-19 were on labour and available capital rather than land. For example, casual labourers were less able to get work, while movement restrictions meant that farmer-employers struggled to find workers, even within the same country. Disrupted access to markets had serious impacts, for example on women traders in Tanzania who were not able to participate in the cross-border trade they had formerly relied on. By contrast, larger businesses were more able to bear these impacts by sitting out periods of low sales, and sometimes even continuing to pay workers.

Some benefitted from the hiatus in sales. For example, rice farmers in Ethiopia who could manage to withstand a period of low sales paused selling, anticipating that the cessation of imports from Asia would result in future price rises from which they could later benefit, to the detriment of consumers. More established and larger businesses were also able to take advantage of government or nongovernmental organisation assistance grants and loans.

\section{Inter-temporal interactions}

For many agricultural value chain actors in Africa, COVID-19 has not been the most severe shock they have experienced, while simultaneously resembling other shocks in some ways. Other shocks, for example locusts, drought, war, market collapse and land loss, have highlighted the existing unequal distribution of power and capital in a value chain, as well as the resilience of people engaged in agricultural value chains and livelihoods that are unpredictable.

The initial COVID-19 response showed that those who have resilience capacities were able to move position within the value chain or even move to non-agricultural activities. Actors working at the smallest scale are often pursuing multifunctional livelihoods. Whilst lacking the capital stocks and access to safety nets that can enhance their robustness to shocks, they may have skills to support a resilient response, including experiences learnt from past shocks, for example price fluctuations or new regulations that forbid or encourage imports.

APRA's research also showed important interactions between longand short-term patterns of social differentiation. The larger-scale value chain actors, who are more likely to be advantaged through the long-term processes described above, are also more able to bear the costs of shocks such as COVID-19. While short-term shocks can prove a setback for these actors through effects on labour relations, access to market and capital, they are less likely to recursively make a long-term difference, provided land dynamics remain unchanged. However, if the shock becomes a stress that causes changes in land holding, such as distress sales of land, it is more likely to have a long-term effect. In such circumstances, it is generally women and migrants who are often in the most precarious position in terms of agrarian relations, and who are among the first to be disadvantaged.

Table 1 - Value chains examined in the study

\begin{tabular}{|c|c|c|}
\hline Country & Crop & Overview of the value chain \\
\hline Ghana (Asante, 2021) & Palm oil & $\begin{array}{l}\text { A value chain with women mainly processing and carrying out small-scale production for } \\
\text { local markets; with some larger-scale production for international markets by men. }\end{array}$ \\
\hline Ghana (Teye and Nikoi, 2021) & Cocoa & An important export crop concentrated in the southern part of the country. \\
\hline Nigeria (Aiyede, 2021) & Cocoa & $\begin{array}{l}\text { A less successful cocoa export crop (compared to Ghanaian cocoa) concentrated in the } \\
\text { southern part of the country. }\end{array}$ \\
\hline $\begin{array}{l}\text { Nigeria (Amaza, Mailumo and } \\
\text { Silong, 2021) }\end{array}$ & Maize & An important food crop; modernisation of the sector is underway. \\
\hline Zimbabwe (Shonhe, 2021) & Maize & An important national food crop; strongly state-controlled sector. \\
\hline Zimbabwe (Shonhe, 2021) & Tobacco & $\begin{array}{l}\text { An important crop for national income; liberalised market which was affected by } \\
\text { international sanctions. }\end{array}$ \\
\hline $\begin{array}{l}\text { Malawi (Chinsinga and Matita, } \\
\text { 2021) }\end{array}$ & Groundnut & The most important legume crop in the country; fluctuating production and export levels. \\
\hline $\begin{array}{l}\text { Tanzania (Isinika and } \\
\text { Jeckoniah, 2021) }\end{array}$ & Sunflower & $\begin{array}{l}\text { National food crop growing in importance; unable to compete on international markets } \\
\text { due to high price of the crop. }\end{array}$ \\
\hline $\begin{array}{l}\text { Tanzania (Mdoe and Mlay, } \\
\text { 2021) }\end{array}$ & Rice & Important for national consumption and export. \\
\hline $\begin{array}{l}\text { Ethiopia (Alemu and Assaye, } \\
\text { 2021) }\end{array}$ & Rice & $\begin{array}{l}\text { Important food crop that is increasing in popularity; locally grown varieties cannot } \\
\text { compete with imported basmati. }\end{array}$ \\
\hline Nigeria (Aiyede, 2021) & Rice & $\begin{array}{l}\text { Important food crop where smallholders are increasingly supported within contract } \\
\text { farming; the government controls imports to protect the sector. }\end{array}$ \\
\hline
\end{tabular}


For the time being, COVID-19 is more of a shock that accentuates existing longer-term patterns of social differentiation. Early data did not show that COVID-19 had caused changes that could have a longer-term impact on agrarian relations. However, these types of eventualities could become possible as COVID-19 becomes endemic, with cuts to foreign aid budgets and unequal access to vaccines globally reinforcing structural inequalities in the rate at which different countries, social groups and the agricultural sector are able to recover from the pandemic. It could then become more of a stress than a shock.

\section{Key policy messages}

Short term advantage can be conferred to various political groups through the manipulation of access to movable inputs. Longer-term advantage can be conferred to smallholders through the general development of infrastructure that supports their businesses, such as investment in public goods and services, as well as access to markets with stable, reasonable prices. It is also important to address social differentiation in land tenure through measures to facilitate landless labourers' access to land and other livelihood opportunities.

The structures that support agricultural actors in the long term will have a direct bearing on how well they are able to survive shocks such as COVID-19. This could be just as important as short-term support to helping them navigate such crises.

State support to smaller-scale actors in moments of crisis can include:

- ubiquitous access to loans;

- government mobilising structures like marketing boards, which can continually purchase goods to keep small-scale actors' businesses going;

- cash support to labourers who cannot get work; and

- facilitating the movement of labourers to small-scale employers

Governments are not able to do this without fast donor support. The actors to pay attention to are women, migrants, the young, the landless, some ethnicities and smaller businesses in general.

Targeted domestic policy measures are therefore needed to support less advantaged groups. The withdrawal of foreign aid, including UK aid, that could benefit more vulnerable social groups contributes to this picture.

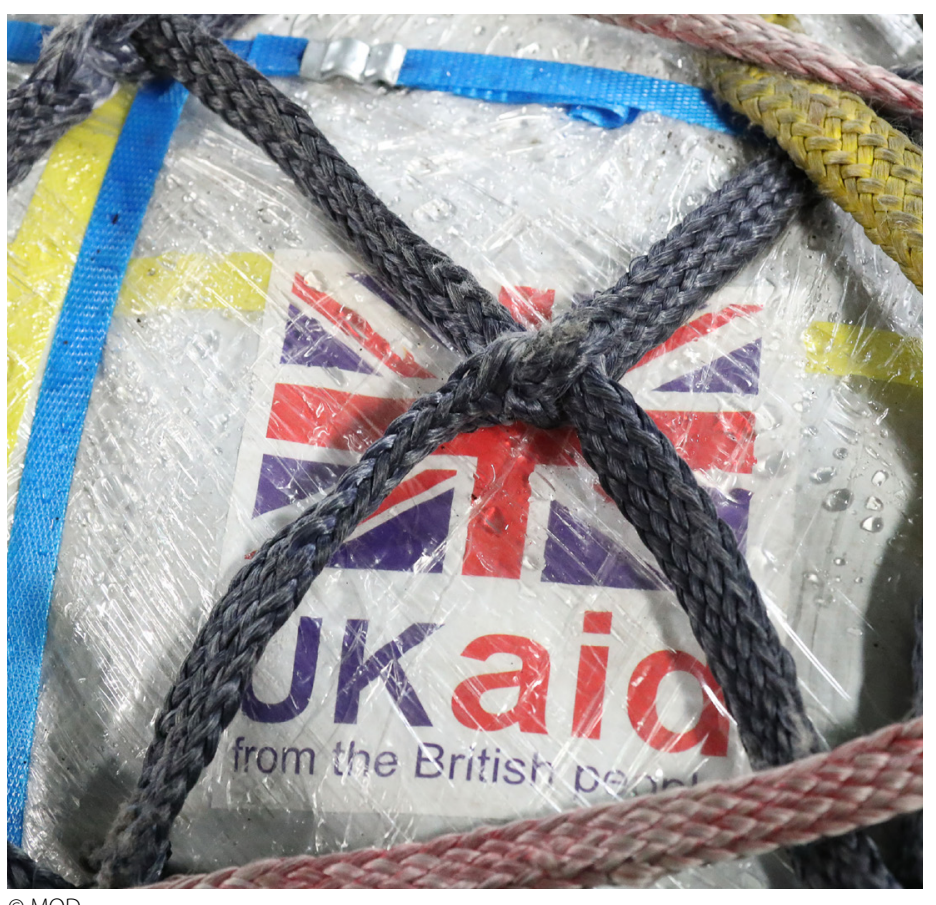

(c) $\mathrm{MOD}$ 


\section{References}

Aiyede, E.R. (2021) Agricultural Commercialisation and the Political Economy of Cocoa and Rice Value Chains in Nigeria. APRA Working Paper 52. Brighton: Future Agricultures Consortium. Available at: https://opendocs.ids.ac.uk/opendocs/handle/20.500.12413/16462 (Accessed: 11 November 2021).

Alemu, D. and Assaye, A. (2021) The Political Economy of the Rice Value Chain in Ethiopia: Actors, Performance, and Discourses. APRA Working Paper 51. Brighton: Future Agricultures Consortium. Available at: https://opendocs.ids.ac.uk/opendocs/handle/20.500.12413/16460 (Accessed: 11 November 2021).

Amaza, P., Mailumo, S. and Silong, A. (2021) The Political Economy of the Maize Value Chain in Nigeria. APRA Working Paper 60. Brighton: Future Agricultures Consortium. Available at: https://opendocs.ids.ac.uk/opendocs/handle/20.500.12413/16741 (Accessed: 11 November 2021).

Asante, K.T. (2021) Political Economy of the Oil Palm Value Chain in Ghana. APRA Working Paper 54. Brighton: Future Agricultures Consortium. Available at: https://opendocs.ids.ac.uk/opendocs/handle/20.500.12413/16677 (Accessed: 11 November 2021).

Bellwood-Howard, I. and Dancer, H. (2021) Politics, Power and Social Differentiation in African Agricultural Value Chains: The Effects of COVID-19. APRA Working Paper 69. Brighton: Future Agricultures Consortium. Available at: https://opendocs.ids.ac.uk/opendocs/ handle/20.500.12413/16866 (Accessed: 11 November 2021).

Chinsinga, B. and Matita, M. (2021) The Political Economy of the Groundnut Value Chain in Malawi: Its Re-emergence Amidst Policy Chaos, Strategic Neglect and Opportunism. APRA Working Paper 56. Brighton: Future Agricultures Consortium. Available at: https://opendocs.ids.ac.uk/opendocs/ handle/20.500.12413/16679 (Accessed: 11 November 2021).

Isinika, A. and Jeckoniah, J. (2021) The Political Economy of Sunflower in Tanzania: A Case of Singida Region. APRA Working Paper 49. Brighton: Future Agricultures Consortium. Available at: https://opendocs.ids.ac.uk/opendocs/handle/20.500.12413/16459 (Accessed: 11 November 2021).

Kelsall, T. and vom Hau, M. (2020) Beyond Institutions: Political Settlements Analysis and Development IBEI Working Paper 56. Barcelona: Institut Barcelona d'Estudis Internacionals. Available at: https://www.ibei.org/en/beyond-institutions-political-settlements-analysis-anddevelopment_208952 (Accessed: 18 November 2021).

MasterCard Foundation (no date) 'Youth-Led Creative Enterprise Adapts to Curb the Spread of COVID-19 in Tanzania', MasterCard Foundation [online]. Available at: https://mastercardfdn.org/youth-led-creative-enterprise-adapts-to-curb-the-spread-of-covid-19-in-tanzania/ (Accessed 11 November 2021).

Mdoe, N.S.Y. and Mlay, G.I. (2021) Agricultural Commericalisation and Political Economy of Value Chains: Tanzania Rice Case Study. APRA Working Paper 57. Brighton: Future Agricultures Consortium. Available at: https://opendocs.ids.ac.uk/opendocs/handle/20.500.12413/16680 (Accessed: 11 November 2021).

O’Rourke, C. (2017) ‘Gendering Political Settlements: Challenges and Opportunities', Journal of International Development 29: $594-612$.

Shonhe, T. (2021) COVID-19 and the Political Economy of Tobacco and Maize Commodity Circuits: Makoronyera, the 'Connected' and Agrarian Accumulation in Zimbabwe. APRA Working Paper 55. Brighton: Future Agricultures Consortium. Available at: https://opendocs.ids.ac.uk/ opendocs/handle/20.500.12413/16678 (Accessed: 11 November 2021).

Teye, J.K. and Nikoi, E. (2021) The Political Economy of the Cocoa Value Chain in Ghana. APRA Working Paper 53, Brighton: Future Agricultures Consortium. Available at: https://opendocs.ids.ac.uk/opendocs/handle/20.500.12413/16676 (Accessed: 11 November 2021). 
Dancer, H. and Bellwood-Howard, I. (2021) COVID-19 and Social Differentiation in African Agriculture, APRA Brief 28, Brighton: Future Agricultures Consortium

(cc) BY-NC-ND

This is an Open Access report distributed under the terms of the Attribution-Non Commercial-No Derivs 4.0 Unported (CC BY-NC-ND 4.0) Attribution - You must give appropriate credit, provide a link to the license, and indicate if changes were made. You may do so in any reasonable manner, but not in any way that suggests the licensor endorses you or your use. NonCommercial — You may not use the material for commercial purposes. NoDerivatives - If you remix, transform, or build upon the material, you may not distribute the modified material. You are free to: Share - copy and redistribute the material in any medium or format.

https://creativecommons.org/licenses/by-nc-nd/4.0/legalcode

If you use the work, we ask that you reference the APRA website (www.future-agricultures.org/apra/) and send a copy of the work or a link to its use online to the following address for our archive: APRA, Future Agricultures Consortium, University of Sussex, Brighton BN1 9RE, UK (apra@ids.ac.uk)

\section{@creative}

Agricultural Policy Research in Africa (APRA) is a programme of the Future Agricultures Consortium (FAC) which is generating new evidence and policy-relevant insights on more inclusive pathways to agricultural commercialisation in sub-Saharan Africa. APRA is funded with UK aid from the UK Foreign, Commonwealth \& Development Office (FCDO) and will run from 2016-2022.

The APRA Directorate is based at the Institute of Development Studies (IDS), UK (www.ids.ac.uk), with regional hubs at the Centre for African Bio-Entrepreneurship (CABE), Kenya, the Institute for Poverty, Land and Agrarian Studies (PLAAS), South Africa, and the University of Ghana, Legon. It builds on more than a decade of research and policy engagement work by the Future Agricultures Consortium (www.future-agricultures.org) and involves more than 100 researchers and communications professionals in Africa, UK, Sweden and USA. 